\title{
MBA programs and their perspectives on the regional level in Russian Federation
}

\author{
Irina Stikhina \\ Ural State University of Economics, 620144, 8 Marta Street 62, Ekaterinburg, Russia
}

\begin{abstract}
This article considers the availability of business schools and MBA programs on the Russian educational market and, in particular, in one of the federal subjects of Russian Federation, Sverdlovsk oblast. The market of MBA programs is reviewed on federal and regional levels and possible further way of development is suggested. In order to reach this goal, the ratings of business schools in Russia, information about them are analyzed and the general trends are defined. The survey confirms the lack of regional MBA programs on the market. Possible advantages of the availability and perspectives of programs with the regional focus are described. Partnerships between regional universities of economics and recognized foreign business schools are presented as the option for further development of MBA programs on the regional level. The Ural State University of Economics is given as an example.
\end{abstract}

\section{Introduction}

Business education and MBA programs started becoming successful in the 1980's. According to the Association to Advance Collegiate Schools of Business (hereafter AACSB), by the end of the 1980's there was a 23 percent rise in the overall percentage of MBA graduates [1]. Despite the criticism about MBA curricula, MBA programs have grown and gained popularity for 30 years afterwards. Since the 1990's business schools have been evaluating their MBA content critically and faculties have been constantly adapting the curricular not only to the needs of the industry but also to crucial social changes. Incorporation of ethics, responsibility, and sustainability in management education is the research topic of scientific studies today [2, 3]. Cotton et al. already in 1993 emphasized a mission-based approach acknowledging heterogeneous nature of business schools and capitalizing on individual strengths: business schools differ with regard to resources and objectives across the nations and "...these differences would need to be incorporated and sanctioned, within the accreditation process" [4, p. 17].

Nowadays the variety of MBA programs creates competitive environment in business education. This competitiveness is integral to constant improving and providing high quality business education to students. A lot of programs are available in an online format globally. Still, the accessibility of classic and blended MBA programs is valuable according to the research. The purpose of this particular study is to suggest the further development of MBA programs in Sverdlovsk oblast based on the analysis of the MBA market in this region and in Russian Federation, in general. 
The objectives of the research are to review the history of MBA and the development of MBA programs in the USA, Europe and Russia; to specify the general purpose, content of MBA programs and their target audience; to consider the occurrence of main accreditation systems for MBA programs and explain their key features; to review different education formats in terms of MBA programs and perspectives of partnerships between business schools from different countries.

Firstly, a brief overview of the MBA history will be presented. Business schools in Europe have quite a long history. The first business school was created in France in 1819, Ecole Superieure de Commerce Europe. Already that first school emphasized the international approach: it had seventy-five percent of international students, ten foreign languages were included in its curriculum [5]. The second institution was founded in Belgium in 1852. Further European schools used the same model based on combination of theoretical and practical approach to business education and interdisciplinary curriculum.

Of course, European schools were not the first business schools in the world. US business education had already included trade schools since the late $18^{\text {th }}$ century. However, the vocational education couldn't meet the demand in managers and leaders which were needed for solving problems and implementing innovations in the world of rapid technical changes. Therefore, more academic approach to business education was expected in the society, and this factor stimulated the creation of university-based business schools. Joseph Wharton founded the Collegiate School of Business at the University of Pennsylvania in 1881 where he promoted both commercial training and the classical college education. According to him, it could serve the appropriate level of business education to the efficient managers [6].

It is considered that the first business school which offered the MBA degree was the Harvard Business School founded in 1908. It didn't demonstrate the international approach and was focused on "a liberally educated class of leaders for American society" [7, p. 20]. However, several years before that, the Tuck School of Business, one of three professional schools of Dartmouth College, was founded as the world's first graduate school of management. It served as the prototype for the graduate business school conferring the MBA degree [8].

The popularity of business education has constantly grown since the 1920's. The figures prove intense development: in 1919 there were only 110 degrees in the USA, and in 1949 4300 [6]. The curriculum started to concentrate on analytical methods to improve "business planning and decision-making" [9, p. 14]. After publishing two "Foundation Reports" in 1959, the demand for innovative up-to-date curricula, responsiveness and improvement of business education became more obvious. According to Gordon and Howell, the industry needed leaders who were capable of adopting changes and possessed the corresponding skills and flexibility [10]. These leaders' characteristics are still in demand nowadays.

After considering some key stages of business education, we'll specify the main international accreditation systems, which elaborate standards to assess MBA programs and business schools.

Global nonprofit association AACSB was founded in 1916 as the Association of Collegiate Schools of Business. The first general meeting was held in November 1919 at Harvard University where members discussed the elements of the curriculum and their proper balance, teaching of law, relation of business schools to the secondary school system etc. [11]. Developing procedures and standards for accreditation were based on scientific business research. Ford Foundation approved several impressive grants to support some programs and activities of the Association. Since 1960's the influence of the Association grew: in 1968 it accredited the first school outside the US (University of Alberta, Canada), in 1997 the first school outside North America - ESSEC Business School in France. Nowadays the Association has its media, holds different conferences, seminars and forums, 
publishes researches, reports and studies and revises accreditation standards to be more accommodating of business school structures in other countries that differ from the traditional US model. It has its own career center platform [12] and is the oldest and the most authoritative accreditation agency in the world [13]. AACSB provides quality assurance, business education intelligence, and learning services to over 1,700 member organizations and more than 840 accredited business schools worldwide [12].

Another accreditation system was presented in 1997 in Europe. As A. Djalali states, this was the beginning of Europe's (re)emancipation process and became a milestone in the settings of European business schools. The EQUIS (European Quality Improvement System) has its own focus which quite differs from the one of AACSB. For example, the EQUIS requires internationalization, focuses more on the general strategy and uniqueness of the school, whereas AACSB concentrates on the quality of curriculum design [9, p.16]. EQIOUS accreditation also expanded outside Europe: in 1999 the first non-European school (HEC Montreal) was awarded [11].

The third organization, which accredits MBA programs and is the last element of the so called Triple Accreditation, is the AMBA (Association of MBAs) which was founded earlier, in 1967 in London. This association accredits only the MBA portfolio of a business school but not the school as an entity. It has therefore the narrowest scope. According to the information from the online portal "MBA today", in August 2020, 102 business schools in the world held the "triple crown" accreditation from the most sought-after international accreditations: AACSB, AMBA, EQUIS. 65\% of these institutions are based in Europe [13]. It should be also mentioned that the international accreditation systems above are not the only ones that exist.

In the next part the methodology of the research will be presented as well as the development of MBA programs in Russia.

\section{Materials and methods}

In order to consider Russian and, in particular, regional MBA market (Sverdlovsk oblast) the quantitative content analysis was used in the current research. Such open sources as websites, analytical reports, research papers were studied to consolidate and analyze the textual data. The inductive and deductive methods as well as the comparative method and elements of prognostic method enabled the processing of the data, further interpreting and prognosis.

In Russia, the history of MBA started in the 1990's. Nowadays many institutions offer business education to people who want to become successful leaders. Not all business schools have recognized accreditations. Actually, according to the popular online portal «MBA in Moscow and Russia», which positions itself as the main sauce of information about business education in Russia, only one business school in Russia has the AACSB accreditation. It is the Institute of Business Studies and Business Administration at the Russian Presidential Academy of National Economy and Public Administration (RANEPA). This institute also has the AMBA and NASDOBR accreditation. The last one is the National Accreditation Council of Business Education in Russia. It is a noncommercial partnership founded in 2012. The aim of this organization is to create the independent assessment system of the quality of business and management education in Russia and to accredit national programs of continuing professional education [14]. Among its founders there are such organizations as Russian Union of Industrialists and Entrepreneurs, the Chamber of Commerce and Industry of the RF, Russian Association of Business Education and others. Currently, different MBA programs in 17 educational institutions have this accreditation [15]. 
Two Russian business schools have EQUIS accreditation: Moscow School of Management Skolkovo and Graduate School of Management at St. Petersburg University. 14 business schools have the AMBA accreditation.

Of course, if a business school doesn't have an accreditation, it doesn't mean that it can't be trusted. The process of accreditation can last many years. Sometimes, business schools become members of the associations without being accredited. However, the availability of the accreditation is an important benchmark which guarantees the quality and high standards of business education.

In Ekaterinburg, the capital of Sverdlovsk oblast, which is a large industrial city, there are not so many options for students who want to get an MBA degree. Of course, nowadays there are plenty of online courses worldwide. According to the studies, already in 2018 the number of online MBA students in Russia reached 3300. The total number of MBA degrees was then about 7000 [16]. So, blended MBA and classic MBA programs were in demand (more than $50 \%$ of the total number of students chose them). These programs suggest that students participate in different arrangements in person. The availability of such MBA programs, where people can communicate and exchange their experience face-to-face, still remains important and such formats will be in demand in the future.

In Russia, the most significant competition we can observe between MBA programs which are offered by business schools/universities from Moscow and St. Petersburg. 29 from 34 business schools, which are in the rating, are located there. Only a few of them (5) represent other regions (Kazan, Ekaterinburg, Samara, Novosibirsk, N. Novgorod) [15]. This new rating is based on the assessment of programs that alumni provide. According to the survey, these 34 business schools represent $96 \%$ of national market in the field of MBA and EMBA programs. We also can state that $85 \%$ of institutions from the survey are business schools/universities from Moscow and St. Petersburg, but only $15 \%$ of them represent regional MBA programs. It becomes clear that the regional market share is not significant. There are 85 federal subjects in the Russian Federation and all of them have their specific economic features. Due to this reason it is so important to develop regional MBA programs which aim at supporting of regional economy and wealth: it means to educate leaders who are capable of creating and improving business environment in their home regions, being able, at the same time, to implement their knowledge globally. Thus, leaders would be able to create efficient international business connections which are so important for developing at the regional level.

\section{Results}

In Sverdlovsk oblast, which is an important industrial region in Russia, there are a few business schools which provide MBA education. The well-known one is the Business School of the Ural Federal University named after the first President of Russia B.N. Yeltsin (URFU), which is located in Ekaterinburg. It has the $15^{\text {th }}$ place in the rating mentioned above. According to another rating, which shows the popularity of the leading business schools in Russia measuring the users' interest to the information these schools provide (the number of parameters is included, among them, browsing the websites and the news, the number of clicks to the sites of business schools etc.), the Business School of the URFU has the $4^{\text {th }}$ place from nine: 110 views in December 2020 (according to this rating, 20 is the lowest number of views for the Highest Business School of the Southern Federal University in Rostov-on-Don; the largest one is for the Institute of Business Studies and Business Administration of the RANEPA - 1146) [15]. The Ural-Siberian Institute of Business (USIB) positions itself as the leading business school of the Ural-Siberian region. It also offers different MBA programs and has a number of awards [17], the position in the rating of popularity is the $6^{\text {th }}$ (30 views) [15]. 
Only the Business School of the URFU is mentioned in the report "Russian MBA and business-education market in 2019" conducted by "RosBusinessConsulting" (RBC). It includes experts' interviews, ratings of business schools, analysis of trends and market dynamics, prognosis etc. [18]. Apart the Business School of the URFU, several business schools from other regions are also mentioned, but schools from Moscow and St. Petersburg prevail.

The Ural State University of Economics (USUE), which is the unique regional university in Ekaterinburg and Sverdlovsk oblast majoring in economics and management, has offered MBA programs [19], but currently they need resuming-and reloading. The university has close connections with industrial and commercial enterprises of the region. A lot of alumni with great managerial experience can share their skills and knowledge with managers who only have a little experience in the field and want to foster their skills. What is especially important, the focus on regional economy, the knowledge about its specific features could give insights to managers whose companies operate in the region and strive to expand beyond it.

One of the ways to restart these programs is to cooperate with foreign business schools which have recognized positions, including accreditation and ratings. Successful joint MBA programs with partners are common in the MBA market. Different Internet portals that aggregate data about business schools, MBA students and people looking for MBA degrees mention such programs. For example, the portal "MBA today" displays 66 MBA programs in Russia [13], some of them provide foreign business schools (e.g. Kingston Business School, Antwerp Management School, Stockholm School of Economics) while others are offered by foreign business schools in partnership with Russian institutions (e.g. Grenoble Ecole de Management in partnership with the Institute of Business Studies/RANEPA in Moscow; Moscow School of Social and Economic Sciences in cooperation with Kingston Business School). Some of the content can be taught in English and some in Russian. The percentage differs.

\section{Discussion and conclusion}

So, as we can assume, partnerships only facilitate the promotion of business education and improve its quality: teachers represent different mentalities and approaches delivering unique content and enriching students' pool of skills and competencies. Besides, such collaboration can give rise to unique implementation formats of curricular.

More and more different technological tools are used to achieve educational results. Nowadays there are blended programs with live and not live sessions; MOOCs (Massive Open Online Courses) with different combinations of synchronous and asynchronous components including virtual classes, using of different e-learning platforms, applications, digital assessment tools etc. These options enable and facilitate partnerships in terms of MBA programs worldwide.

Some educators emphasize that creating engagement is the most important value while getting online education. To foster the engagement they suggest thorough cooperation between faculty staff and IT specialists to combine different educational components in compliance with teaching objectives. Of course, engagement is easier to create on campus where people can communicate in person. Still, even within classical learning digital technologies can increase the engagement of programs' participants. For example, in terms of Agile Project Management, where regular team meetings should review progress of a single development phase (or sprint) [20], online meetings are easier to arrange.

All the variety of up-to-date teaching methods and educational technologies are available and used in MBA programs. Educational institutions are interested in cooperation, finding new partners and expanding their market shares. Apart the websites of business 
schools, special Internet platforms promote MBA programs. They enable people seeking for business education to make the right choice providing them with a lot of information about existing programs and other things related to business education [e.g. 21, 15].

In the situation of the competition, the role of MBA programs with the regional focus shouldn't be underestimated. MBA programs are designed for people who already have managerial experience and want to improve their skills in order to lead the companies, organizations and teams to success. Such leaders can be especially significant for the sustainable regional development.

The cooperation with recognized foreign business schools could enable regional universities of economics, e. g. the USUE in Sverdlovsk oblast, to create valuable and attractive MBA programs for students with leading potential within the region as well as for Russian and international students seeking for qualitative business education and interested in sustainable developing of their regional economies

\section{References}

1. Association to Advance Collegiate Schools of Business, The International (2001, Winter). Number of undergraduate and master's degrees awarded is on the upswing; doctorial degrees decline. DOI: http://www.aacsb.edu/publications/printnewsline/NL2001/wnadvocacy.asp

2. Hartman, L.P., Werhane, P.H. A Modular Approach to Business Ethics Integration: At the Intersection of the Stand-Alone and the Integrated Approaches. J Bus Ethics 90, 295 (2009). https://doi.org/10.1007/s10551-010-0427-z

3. Fornes, G., Monfort, A., Ilie, C., Koo, C.K., Cardoza, G. Ethics, Responsibility, and Sustainability in MBAs. Understanding the Motivations for the Incorporation of ERS in Less Traditional Markets Sustainability (Switzerland), 11 (24). (2019) DOI: $10.3390 / \mathrm{su} 11247060$

4. C. C. Cotton, J. F. McKenna, S. van Auken, \& R. A. Yeider. Mission orientations and deans' perceptions: Implications for the new AACSB accreditation standards. Journal of Organizational Change Management, 6 (1). 17 (1993)

5. A. Renouard, Histoire de l'École supérieure de commerce de Paris. Paris: Raymond Castell editions 316 (1999)

6. C. A. Daniel, MBA: The first century. Cranbury, NJ: Associated University Presses 330 (1998)

7. S. A. Sass, The pragmatic imagination. A history of the Wharton School 1881-1981. University of Pennsylvania Press, Philadelphia 351 (1982)

8. Tuck School of Business at Dartmouth. History. DOI: https://www.tuck.dartmouth.edu/about/facts-and-figures/history

9. A. A. Djalali. Didactic perspective on leadership education - focusing on the development of competencies within MBA programs. Steinbeis-Edition, Stuttgart 234 (2017)

10. R. A. Gordon, J. E. Howell. Higher education for business. Columbia University Press, New York, 492 (1959)

11. Association to Advanced Collegiate Schools of Business (AACSB). DOI: https://www.aacsb.edu/about/who-we-are/timeline

12. AACSB Career Connection. DOI: https://careerconnection.aacsb.edu/

13. MBA today. DOI: https://www.mba.today; https://www.mba.today/guide/tripleaccreditation-business-schools; program $=$ all\&search-country $=$ Russia

14. National Accreditation Council of Business and Management Education in Russia. Mission, goals and objectives. DOI: https://nasdobr.ru/nasdobr/goals 
15. MBA in Moscow and Russia. DOI: https://www.mba.su/shkoly_s_rossijskoj_akkredit; https://www.mba.su/narodnyj_rating_bschools_2020; http://www.mba.su/popularity

16. Business and Finance. MBA market in Russia continued its growth at the account of the online segment, 19.07.2019. DOI: https://ria-news.ru/economics/rynok-mba-vrossii-prodolzhil-rost-za-schet

17. Ural-Siberian Institute of Business (USIB). DOI: https://usib.ru

18. Russian MBA and Business Education Market in 2019. Experts' interviews, main trends, dynamics of the market, prognosis of the market development, recognizability of business schools, ratings. DOI: file://C:/Users/User/PrintHood/Downloads/62521rynok-mba-i-biznes-obrazovaniia-rossii-2019.pdf

19. MBA business school of the USUE. DOI: http://mba.usue.ru

20. Association for Project Management. What is agile project management? DOI: https://www.apm.org.uk/resources/find-a-resource/agile-project-management

21. Poets\&Quants. Website of higher education content. DOI: https://poetsandquants.com/online-mba-hub in the USA 